\title{
Outcrop conservation: Promoting accessibility, inclusivity, and reproducibility through digital preservation
}

\author{
Brian S. Burnham ${ }^{1, *}$, Clare E. Bond ${ }^{1}$, Peter P. Flaig ${ }^{2}$, Dolores A. van der Kolk ${ }^{3}$ and David Hodgetts ${ }^{4}$ \\ ${ }^{1}$ School of Geosciences, University of Aberdeen, Aberdeen, AB24 3UE, UK \\ ${ }^{2}$ Bureau of Economic Geology, Jackson School of Geosciences, University of Texas at Austin, Austin, Texas 78758, USA \\ ${ }^{3}$ Department of Geography and Environmental Studies, Texas State University, San Marcos, Texas 78666, USA \\ ${ }^{4}$ School of Earth and Environmental Sciences, University of Manchester, Manchester, M13 9PL, UK
}

\begin{abstract}
Outcrops are routinely used for research and education purposes, and are a key component of geoscientific training. Fundamentally, re-evaluation of outcrop observations and reproducibility of results is critical for scientific advancement. Accessibility to the field and outcrops, however, remain problematic for several technical and societal reasons. Advances in the application of digital outcrop models to geoscience research and training have seen a significant rise in recent years due to technological innovation and user-friendly workflows. Herein we discuss the necessity to digitally capture outcrops to preserve them and the natural landscapes that have shaped the Geosciences. Examples of outcrop re-evaluation that reflect sedimentological concept and technique advances, only possible with digital outcrops, is presented. Digitally preserved outcrops' role as milieus for increased accessibility, inclusivity, and scientific reproducibility is discussed. The time has never been more appropriate, and the tools never more accessible, to preserve outcrops and promote a more open and inclusive environment for geoscience research, education, and training.
\end{abstract}

KEYWORDS 3D Outcrop, Digitization, Education, Accessibility, Reproducibility

\section{THE IMPORTANCE OF OUTCROPS}

A ccess to outcrops is critical to the advancement of our knowledge of Earth history, and the forces that control geologic processes, and their products. Outcrops offer geoscientists $2 \mathrm{D}$ and $3 \mathrm{D}$ views of minerals, rocks, faults, folds, bedding, stratal architecture, unconformities, and many other geologic features that can only be seen through field-based investigations. Outcrops are irreplaceable because they are the visible expression of past Earth surface processes and are frequently used as subsurface analogues. Outcrops can include thick rock sequences that record long-term deposition and paleoenvironmental evolution through deep time (Romans \& Graham, 2013), as well as the products of large-scale geological processes (e.g., mountain building, plate tectonics, volcanism).

Careful examination and interpretation of outcrops is fundamental for geoscientific training (Elkins \& Elkins, 2007, Tretinjak \& Riggs, 2008). Advanced outcrop syntheses often underpin the development of innovative ideas (e.g. Van Wagoner et al., 1990). Access to outcrops in any format is therefore critical to the development of future geoscientists, continued training for career geoscientists,

Copyright (c) 2022 by the SEPM Society for Sedimentary Geology

doi: $10.2110 /$ sedred.2022.1.2

Manuscript submitted: 10/29/2021

Manuscript accepted: 12/27/2021

*Corresponding author: brian.burnham@abdn.ac.uk and the advent of scientific breakthroughs. Fundamentally, the discovery, interpretation, re-examination, and re-interpretation of outcrops are critical to the evolution of Geoscience and advanced understanding of Earth processes. Outcrop conservation is therefore critical to this, and importantly for digital conservation, support for accessibility, inclusivity, and reproducibility in the Earth sciences.

\section{NECESSITY FOR DIGITAL PRESERVATION}

Outcrops intrinsically change over time through natural and/or anthropogenic processes, as do the geological stories they tell. As layers are uncovered, the dynamic nature of Earth's processes are revealed through erosion and evolving cross sections that illustrate the spatial and temporal variability of the Earth. Landscape evolution unfortunately provides a 'catch-22' in which erosion is required to unearth geologic history, but these same outcrops will ultimately succumb to continued denudation. If important outcrops are destroyed or covered by vegetation (Fig. 1), the geological story and the interpretations that can be made thereof (e.g., architectural/structural elements and lateral facies variability) is limited and/or lost. Climate change exacerbates this problem and threatens the longterm preservation of key outcrops (Fig. 2) and landscapes (Guzzetti et al., 2003, Wignall et al., 2018). Alarmingly, anthropogenic actions that include the development of com- 

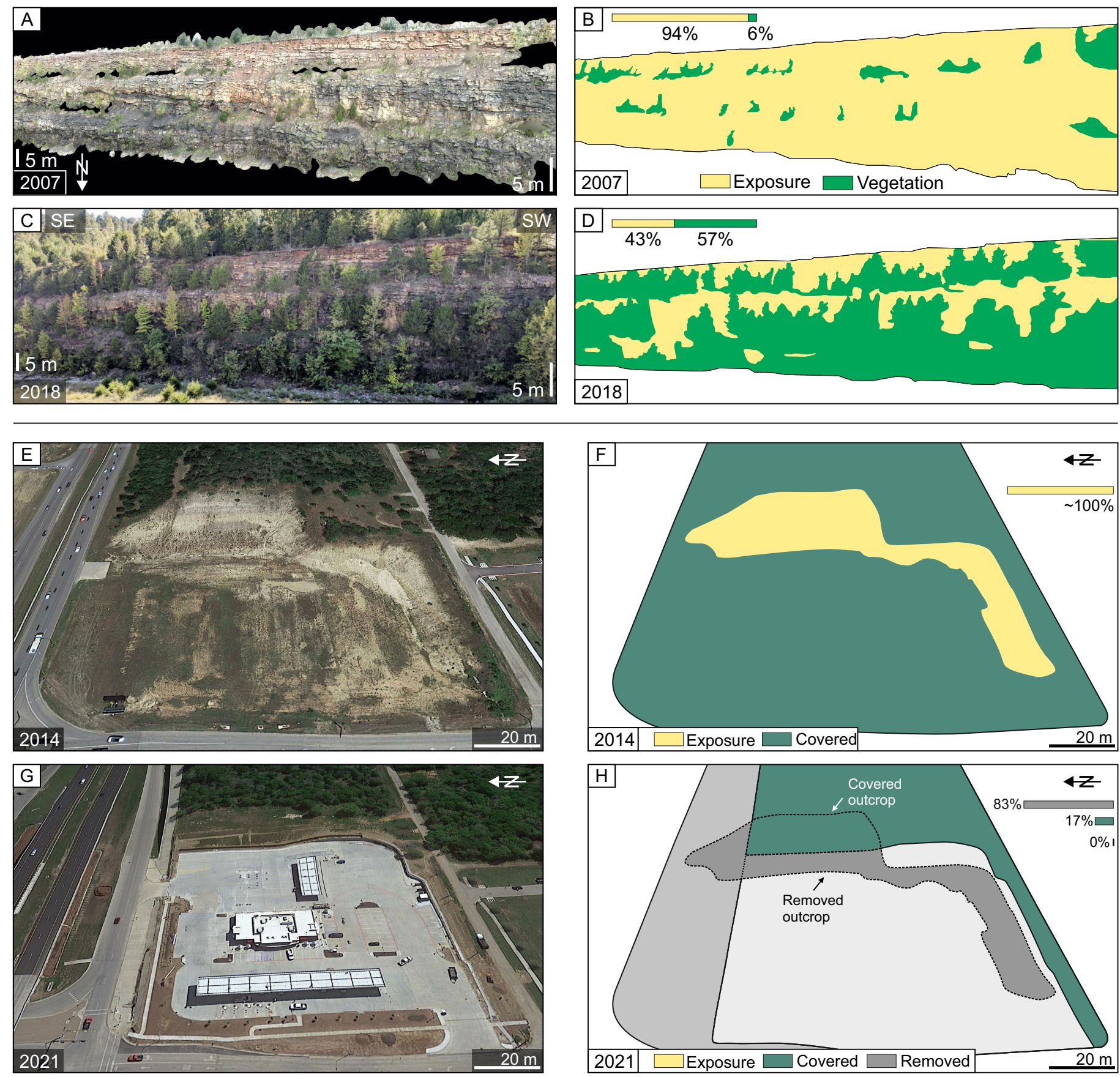

Figure 1: Illustration of vegetation that cover a frequently visited outcrop of a preserved fluvial channel-fill complex in NW Arkansas, USA. (A) A digital outcrop model generated from imagery recorded in 2007 during an undergraduate class fieldtrip visit. (B) Interpretation of exposed facies and approximate vegetation coverage in 2007 from the digital outcrop model. Vegetation covers approximately $6 \%$ of the outcrop. (C) Photograph of the same outcrop in 2018. (D) Interpretation outline of exposed facies and approximate vegetation coverage in 2018. Vegetation ultimately expands to cover approximately $57 \%$ of the outcrop. (E) Google Earth image from 2014 of former outcrop located near Bastrop, Texas, USA. The outcrop exposed the only accessible parasequences of the uppermost Calvert Bluff Fm and lower parasequences of Sabinetown Fm. which contain abundant Ophiomorpha as well as other marine trace fossils and fauna that confirmed the marine nature of the interval (Demchuk et al., 2019). This interval is important to the oil and gas industry for correlation with deeper water Wilcox deposits. (F) Interpretation outline of exposed outcrop facies. (G) Google Earth image from 2021 of the same outcrop that is no longer accessible because it is covered by vegetation and/or removed by infrastructure development. (H) Interpretation of former outcrop exposure covered and/or destroyed by anthropogenic activity. Approximately $83 \%$ of outcrop has been removed by infrastructure development. Vegetation covers approximately $17 \%$ of the remaining original outcrop. 
mercial or residential infrastructure (e.g., roads, bridges), and other human actions that damage or obscure outcrops (Chan \& Kamola, 2017, Nutman et al., 2019), outpace natural denudation by an order of magnitude (B. H. Wilkinson, 2005). This prevents further study of key outcrops (Fig. 1).

Moreover, accessibility to important outcrops may be complicated, problematic, inconsistent, seasonal, or even impossible, preventing scientists from developing new ideas and skills derived from these outcrops. Personal constraints or limitations such as physical disability, financial limitations, carbon footprint reduction, restricted geographical mobility, and safety concerns (Marín-Spiotta et al., 2020, Olcott \& Downen, 2020, Giles et al., 2020) can prove too complex, or problematic, to overcome and prevent fieldwork. Access to outcrops that were previously accessible may no longer be permitted out of safety or environmental concerns (e.g., outcrops are too steep, or biota conservation limits access), because of land ownership changes (Chan \& Kamola, 2017), increased vegetation, or a seasonal climate, weather, or high-latitude location (Senger et al., 2021).

However, technological advances in digital data collection techniques applied to outcrops over the past few decades (Howell \& Burnham, 2021) afford geoscientists with an opportunity to digitally preserve and archive critical geological data (outcrops). There is, therefore, an opportunity to digitize our geoheritage before natural forces destroy these outcrops, or anthropogenic pressures require intervention. This will facilitate greater outcrop accessibility.

\subsection{Geoheritage}

Our geoheritage, and the evolution of Geoscience, are intimately linked to the outcrops where original and fundamental concepts were developed. Fortunately, many of these outcrops are still accessible and available to preserve. For example, a coastal exposure in southeast Scotland near Siccar Point was made famous by James Hutton. This classic outcrop site illustrates the fundamental concept of an angular unconformity (Fig. 3) and was used as evidence for the theory of uniformitarianism (Hutton, 1795). This site remains a well-visited locality by geoscientists. 'Hutton's Unconformity' is part of our relatively short, yet rich geoscience heritage. However, the outcrop remains inaccessible for many visitors. It can only be accessed by navigating a steep, vegetated, and often muddy slope, with the aid of an in-situ rope. This classic and historically important site is now digitally preserved (Fig. 3) and provides access for all geoscientists.

\subsection{Geoconservation}

Geoconservation efforts primarily focus on recognition and preservation of classic sites and landscapes (Burek \& Prosser, 2008). This includes outcrops recognized as sites of outstanding universal value, such as UNESCO Geoparks and World Heritage Sites, which are also at risk. An example of this is the Jurassic coast in the UK, visited by geo- scientists, naturalists, and tourists from around the world. In July 2021 the largest rockfall in the UK for 60 years occurred on the Jurassic Coast, resulting in more than 4,000 tonnes of debris falling onto the shoreline and into the sea (Fig. 4). This event destroyed or obscured a significant portion of the outcrop belt, and part of the World Heritage Site. However, as the cliffs collapse, strata beneath is revealed, thus providing another opportunity to capture a new view of the outcrop. Important sites around the world should be preserved, and as geoscientists, we should strengthen geoconservation efforts by digitally preserving outcrops for future generations of geoscientists and naturalists alike.

\subsection{Accessibility and Inclusivity}

Access to outcrops is a fundamental part of geoscience education and training. This concept is well documented in the geoscience education literature (Elkins \& Elkins, 2007, Tretinjak \& Riggs, 2008, Kastens et al., 2009). Fieldwork is an essential component of most geoscience degrees around the world. This has declined recently however, for example in the US, as geoscience programs move away from traditional field work (e.g., bedrock mapping, stratigraphic analysis) to more applied geological training (e.g., geophysics and remote sensing, laboratory-based geochemistry) (Whitmeyer et al., 2009). The average number of students enrolled in summer field camps, however, has increased (Gonzales et al., 2011). This suggests that fieldbased geological training remains an important part of geoscience education. Educators are therefore researching methods to maximize field-based learning using digital methods (Tavani et al., 2020, Kuckero et al., 2020).

Some outcrops used to illustrate fundamental geological concepts in the field are often located in difficult to access areas (McCaffrey et al., 2005). Additionally, the novel coronavirus SARS-CoV-2 (Covid-19) pandemic has adversely affected field-based research and educational field trips across the geosciences, and the broader scientific community (Geib, 2020), and may continue to do so for some time to come. Border closures and limited transportation, as a result of Covid-19 safety protocols and procedures, have prevented access to field sites and outcrops. This has highlighted accessibility - once again - as a prominent issue in the geosciences.

Significantly, outcrop access is most difficult for those with physical disabilities (Feig et al., 2019, Stokes et al., 2019), and students and scientists from marginalized racial, ethnic, and gender groups (Marín-Spiotta et al., 2020, Olcott \& Downen, 2020, Giles et al., 2020). Academics, educators, and practitioners must acknowledge the limiting and unwelcoming environments that deter students from joining, or indeed continuing their studies, within the geosciences (Marín-Spiotta et al., 2020). Actions must be taken within the geoscience community to address this lack of diversity and inclusivity in the student body, workforce, and organizations (Anadu et al., 2020, Dutt, 2020, Fernandes et al., 2020, Dowey et al., 2021).

As fieldwork will surely continue to be an integral part 

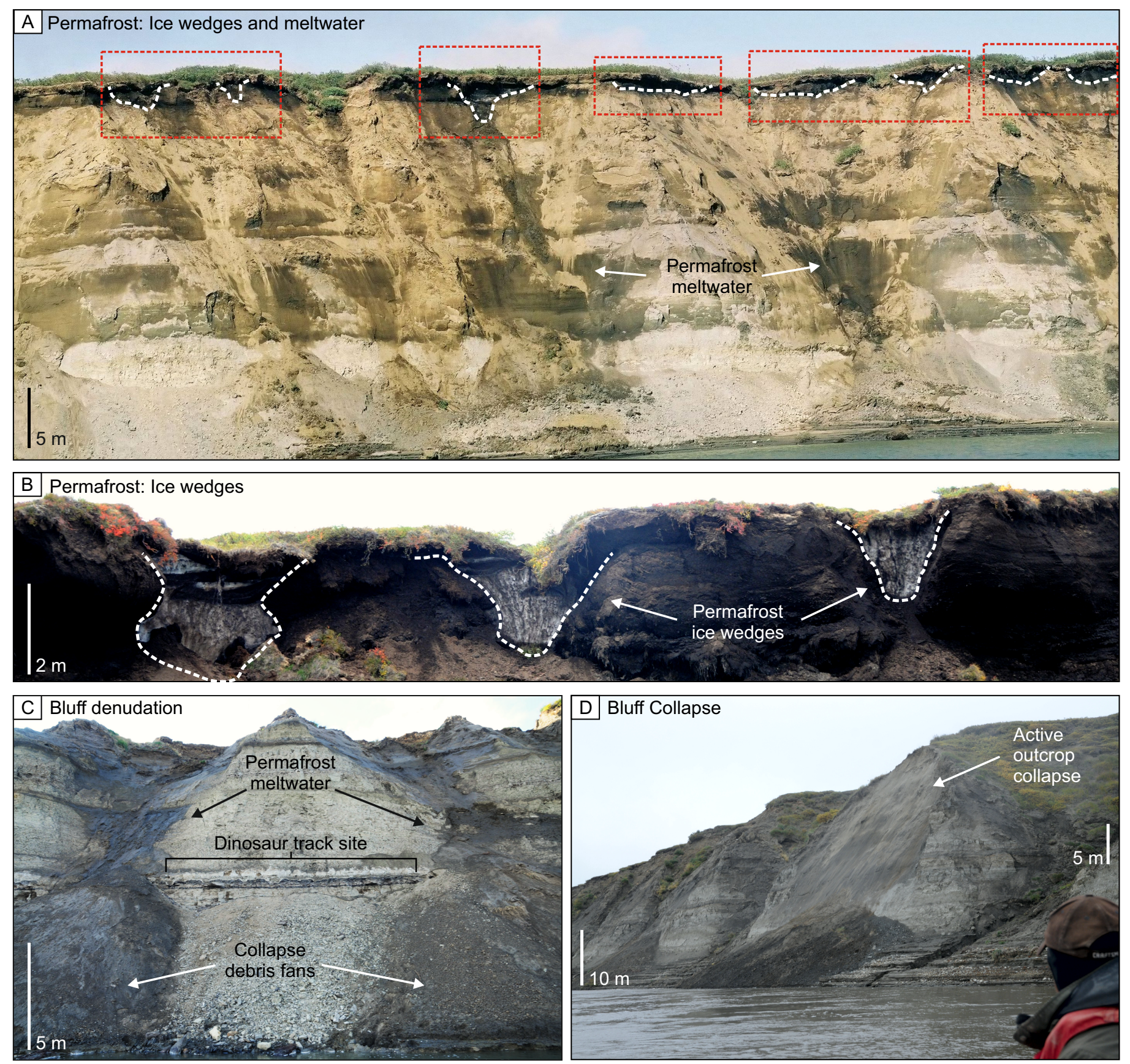

Figure 2: Examples of outcrop denudation along the Colville River on the North Slope of Alaska related to permafrost melt. (A) Permafrost ice wedges at the interface between the outcrop and modern tundra. (B) Detailed view of bluff-top ice wedges. (C) Denudation of Cretaceous stratigraphy and bluff collapse caused by permafrost melt. This process generates debris fans that cover the outcrop and destroys evidence of important stratigraphic and paleontological markers. This site contains an extremely rare layer of Hadrosaur tracks (Flaig et al., 2018). The probability of this locality remaining undamaged for further investigation is low. (D) Bluff collapse caused by combination of river undercutting and permafrost melt. 


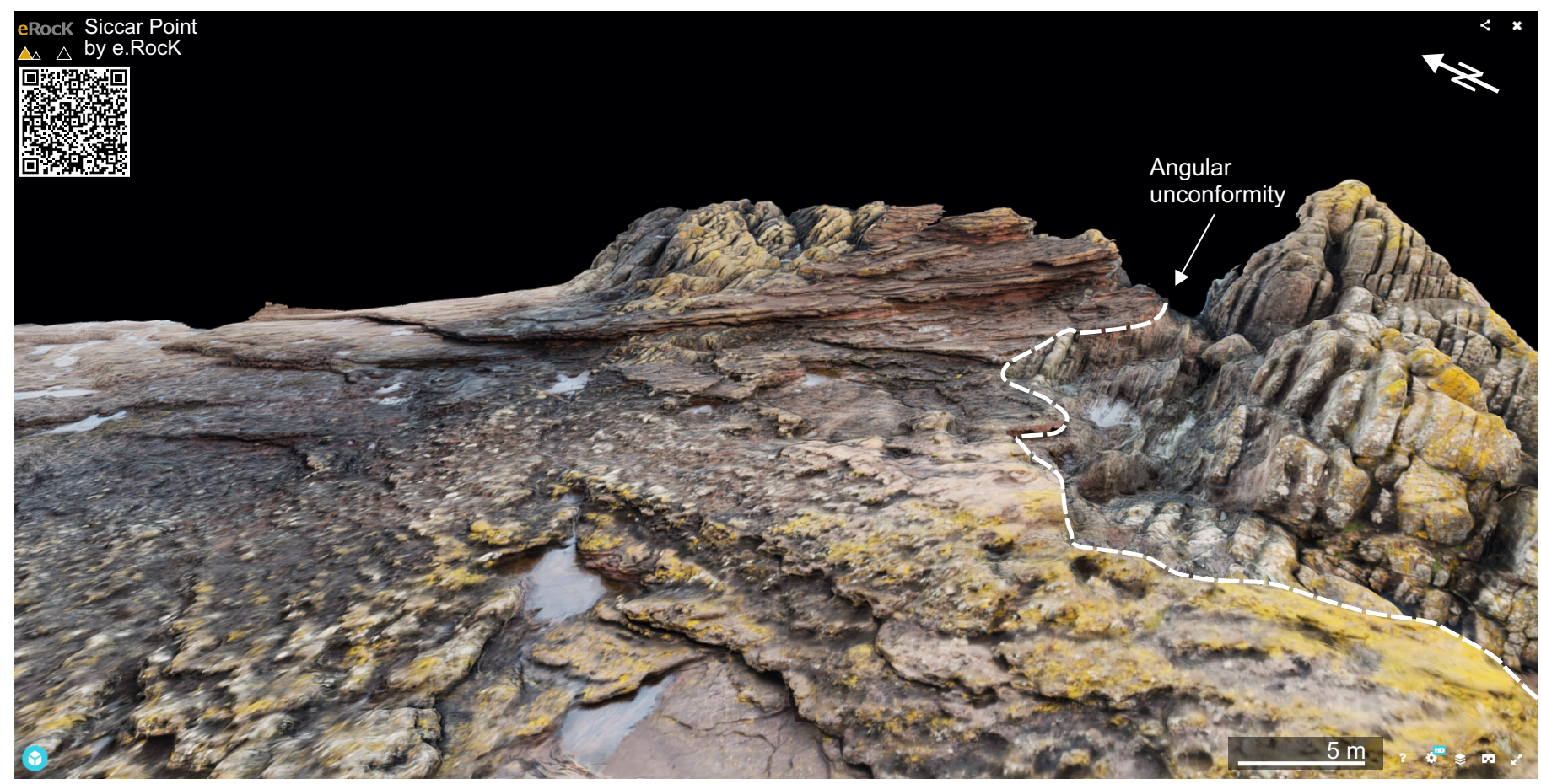

Figure 3: 3D digital outcrop model of the Siccar Point outcrop, which contains the angular unconformity used as evidence for the theory Uniformitarianism proposed by James Hutton. This outcrop is frequently visited by geoscientists. The outcrop is difficult to access due to steep ascents down hillsides, but is also susceptible to coastal erosion. The 3D digital outcrop model of this outcrop, stored on the open access database e-Rock, provides a digital record for Earth science geoheritage.

of geoscience education, the technology and tools exist now to digitally preserve and make accessible digital versions of key outcrops, thus facilitating greater accessibility to 'the field'. Crucially, this digital preservation promotes a more accessible, inclusive, and safer environment for all geoscientists (Fig. 5).

\subsection{Reproducibility}

Reproducibility of observations, data collection, and results are paramount for scientific progress as it encourages transparency and ensures scientific rigor and independent verification. These are vital components of the scientific method (McNutt, 2014). Principles that promote data Findability, Accessibility, Interoperability and Reusability (FAIR) have been created to maximize the "added-value" of scientific data (M. D. Wilkinson et al., 2016). More importantly, these principles endorse open data sharing practices and policies, which have become a pivotal issue in scientific reporting (Nature, 2016). In fact, the term 'Reproducible Research' was coined by geoscientists at Stanford University in the 1990s to eliminate the lengthy process of reproducing results and figures from previous work. The researchers of the Stanford Exploration Project implemented methods such that a small set of standard commands ensures results and figures produced for publications are readily accessible and reproducible (Claerbout \& Karrenbach, 1992, Schwab et al., 1995). Most of the geosciences, unfortunately, have been slow to adopt this practice of digital scholarship, and the discipline is behind other fields in this respect (Gil et al., 2016).

The traditionally descriptive and field-based nature of geoscience data collection and interpretation leaves little room for reproducibility if the outcrops are no longer accessible, or if they no longer exist. A digital (virtual) outcrop revolution at the turn of the century, however, introduced geoscientists to practical methods to quantitatively capture and record outcrops in 3D (Xu et al., 2000, Bellian et al., 2005, Howell \& Burnham, 2021). Digitally preserved outcrops generate a dataset that facilitates the long-term archival of 3D data (outcrop point clouds, surface meshes, source imagery), associated measurements, and interpretations. Digital outcrop data is not limited to large exposures however, even hand sample and core-scale 3D models (e.g. Betlem et al., 2020) can, and should, be generated and archived. Fundamentally, digital outcrop data are inherently quantitative, thus are well placed to bridge the critical gap between outcrop deterioration and continued accessibility, reproducibility, and re-evaluation.

\subsection{Re-evaluation}

Digital outcrop data can be repeatedly re-investigated and re-evaluated as concepts and techniques advance (Nesbit et al., 2020) - key components of the FAIR guiding principles of scientific data (M. D. Wilkinson et al., 2016), and the scientific method (McNutt, 2014), facilitating an open data sharing approach to geological data.

Fundamentally, quantifying sedimentological observations is essential to linking modern geomorphic processes 


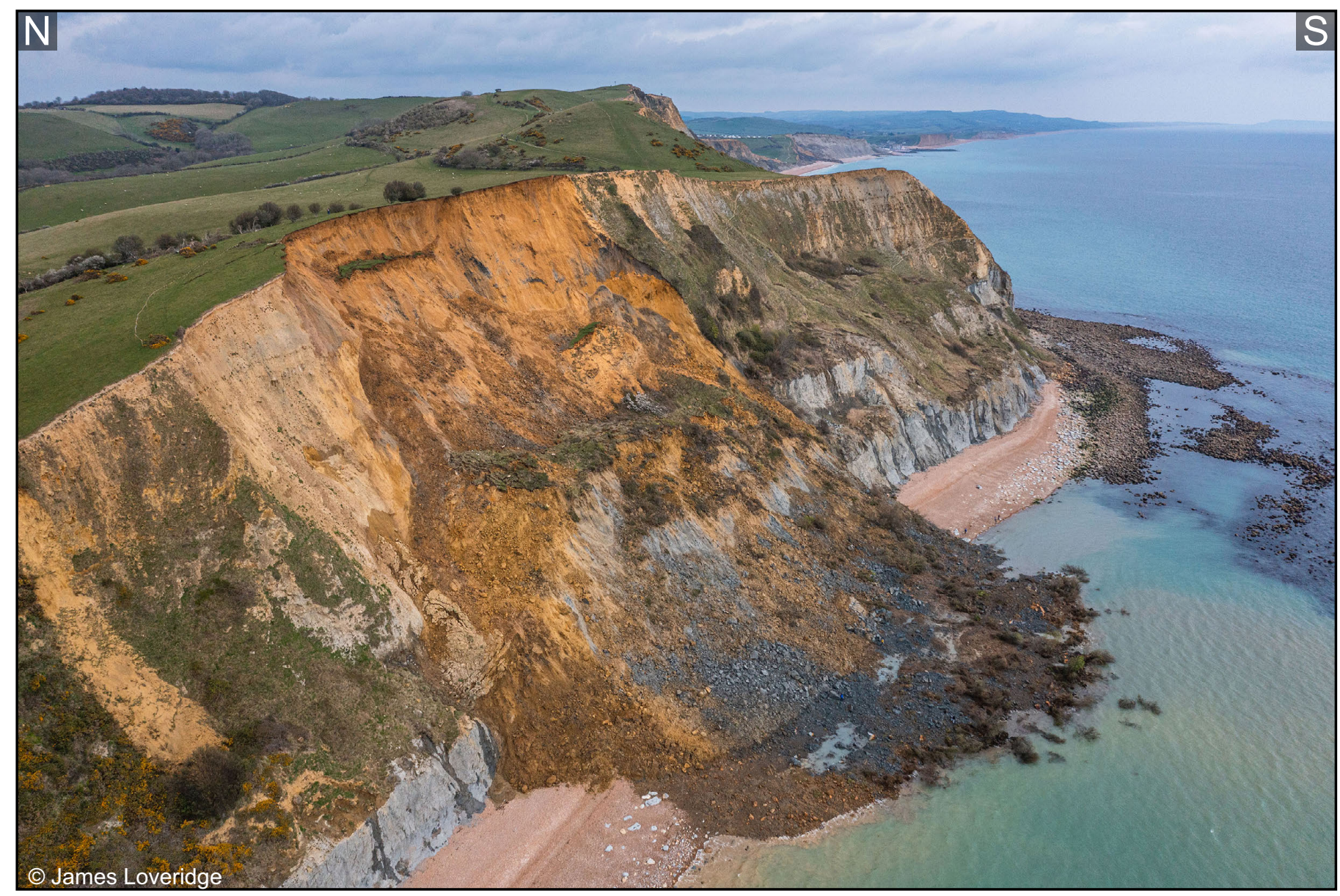

Figure 4: Image of the largest rockfall (greater than 4,000 tonnes of debris) in 60 years, in the UK. The collapse occurred along the Jurassic Coast, a UNESCO World Heritage Site. These important, cliff-forming outcrops are highly susceptible to collapse, deterioration, and destruction. Cliff is approximately $85 \mathrm{~m}$ tall. Photo courtesy of James Loveridge (https://www.jamesloveridgephotography.co.uk/the-jurassic-coasts-biggest-cliff-fall-in-60-years/, April 2021).

to those that controlled what is preserved in the rock record. An example of this is the now widely adopted distributive fluvial system (DFS) model (sensu Weissmann et al. (2010)). The prevalence of these systems in modern continental basins, observable in satellite imagery and in fieldbased investigations, suggests that their deposits may be more common in the rock record than previously identified. For example, the Huesca fluvial system in the Ebro Basin, northern Spain was interpreted as a DFS by Hirst (1992) using traditional data collection and analysis methods. Three decades later, using digital outcrop models and associated quantitative methods, these sections were re-investigated and re-described (Burnham \& Hodgetts, 2019, Martin et al., 2021). Data from the succession could be more precisely quantified with digital outcrop models because the outcrops are steep and difficult to fully access. The digital outcrop models provided a precise spatial position of each measured sandstone body, and their relative relationships. Basin-wide stratigraphic architecture characterization, a difficult task to perform on fluvial outcrops that was not possible for the original investigators, was now undertaken using digital outcrop methods to test the DFS depositional model. The original interpretation of a DFS was ultimately validated using digital outcrop models (Martin et al., 2021).

Another example of outcrop re-evaluation following scientific progression and model testing, is the concept of sequence stratigraphy (Van Wagoner et al., 1990). The extensive Book Cliffs outcrop belt of eastern Utah and western Colorado is where foundational data and criteria behind the development of sequence stratigraphic models was defined (Van Wagoner et al., 1990). The exposed SantonianCampanian sequence has been used for the past 25 years as a 'textbook' example that contains classic features critical for development of the basic sequence stratigraphic model. Recent investigations that analyze kilometer-scale spatial relationships in vertical cliff faces in the Book Cliffs, that are otherwise impossible to characterize without digital outcrop models, have challenged previous concepts of eustatic fluctuations controlling the resultant stratigraphy (Rittersbacher et al., 2014, Howell et al., 2018, Pattison, 2019). Geological models derived from outcrops, in particular outcrops frequently used as subsurface analogues like the Book Cliffs (Pattison, 2019), should be rigorously tested for accuracy because of their significant implications for 
resource exploration and waste storage (Alexander, 1993, Howell et al., 2014). Digital outcrop models provide a robust dataset from which to build geological models and test concepts.

\section{CURRENT DIGITAL OUTCROP PRESERVATION METHODS AND INITIATIVES}

\subsection{Digital and Virtual Outcrops}

Methods to build digital outcrop models (Bellian et al., 2005), or sometimes called Virtual Outcrops (Xu et al., 2000), progressed significantly since the turn of the century (Howell \& Burnham, 2021). The most significant advancement in recent years is related to more accessible and user-friendly workflows that generate high-resolution photorealistic 3D digital representations of outcrops and landscapes using Unmanned Aerial Vehicles (UAV) (Nesbit et al., 2018) and smart phones (Corradetti et al., 2021). Cawood et al. (2017) compare methods of digital outcrop model creation from lidar with ground based and UAV generated photogrammetry, contrasting the relative errors in bed geometry of a well exposed syncline. Howell et al. (2021) discuss bestpractices for robust digital outcrop data collection using UAVs. With an approximate error $(\sim 5 \mathrm{~m})$ associated with internal satellite navigation systems of commercial UAVs, the inclusion of ground control points (GCP) measured using differential GPS in the model will increase positional accuracy. This is a time consuming process, however, if a large outcrop is targeted for capture. Integrated Realtime Kinematic (RTK) navigation systems with UAVs are available, but are cost prohibitive. In most cases, however, the internal navigation system of UAVs is sufficient to accurately position and georeferenced the digital outcrop model.

When combined with ground-truth observations (e.g., geologic maps, sedimentary logs), digital outcrop models are used to elucidate key earth processes such as basinscale controls on sedimentation (Burnham et al., 2020), architectural element characteristics (Mitten et al., 2020), and complex structural relationships (Cawood \& Bond, 2018) that are not achievable without the quantitative spatial context that digital outcrop models provide. Bespoke software Virtual Reality Geological Studio (VRGS) (Hodgetts et al., 2015) and Lime (Buckley et al., 2019) are designed for visualization and analysis of 3D outcrop and geological data of any scale (i.e., millimetric - kilometric). VRGS and Multioutcrop Sharing and Interpretation System (MOSIS) (Rossa et al., 2019) push this further by providing fully immersive digital outcrop experiences.

Alternative to digital outcrop models are other high resolution digital representations of outcrops, such as gigapixel imagery. Gigapixel images offer high resolution data that can be effectively used to characterize large-scale to smallscale features from outcrops that are otherwise inaccessible (Van Der Kolk et al., 2015, Flaig et al., 2019) and that may not be resolvable in digital outcrop models Pitts et al. (2017). Methods that incorporate both digital outcrop models and gigapixel imagery have been used to characterize fine-scale sedimentological features from outcrop (e.g. Frébourg et al., 2016). These methods provide an invaluable resource for detailed investigation of outcrop models. Gigapixel technology and images have also been used as effective virtual teaching tools (Piatek et al., 2012, Senger et al., 2021). Fully integrated digital outcrop models and gigapixel imaging methods show promising results (Biber et al., 2018), and may provide the scale and context that physical fieldwork and outcrop visits also afford, if the outcrops allow for it.

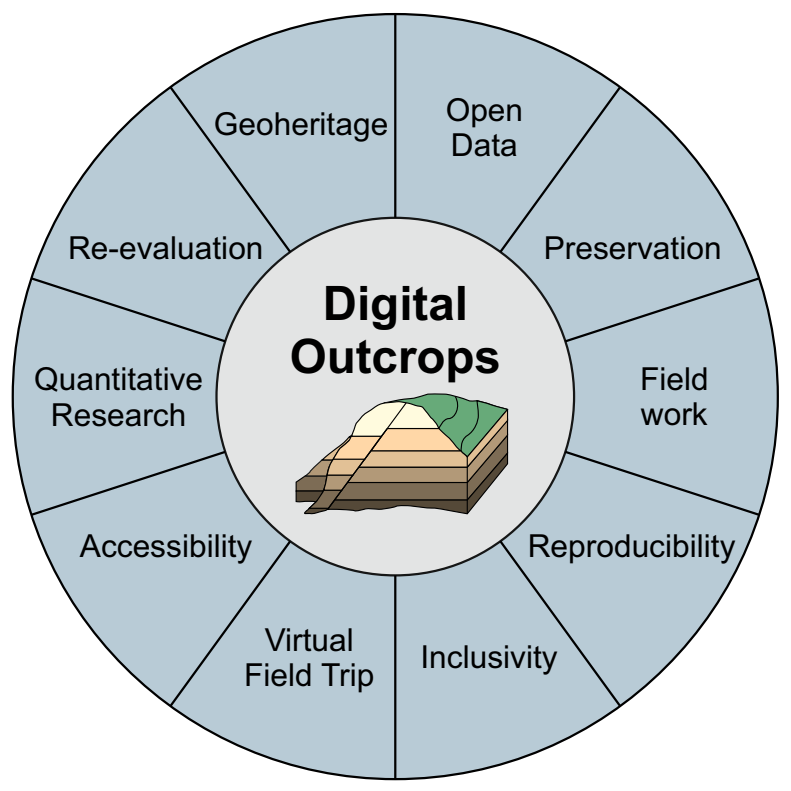

Figure 5: Circular chart that illustrates the interlinked role that digital outcrops play in providing greater accessibility, inclusivity, and reproducibility in geoscience research and education.

\subsection{Databases and Existing Initiatives}

Online digital outcrop model databases (e.g., e-Rock (Cawood \& Bond, 2019), GeoTour3D, V3Geo (Buckley et al., 2021), GeoBase, Svalbox (Senger et al., 2021), Virtual Australia) have seen a rapid increase in generation and use, as do a growing set of geological models hosted on the generic 3D photo-realistic model site Sketchfab. These databases provide a valuable source of digital outcrop models for geoscientists that can be used for research activities, and most recently the development of new online teaching methods driven by the widespread expansion of the virtual classroom due to the Covid-19 pandemic (Sima, 2020). Digital outcrop model databases are currently used, and will be employed in the future, as remarkable tools for virtual learning and training (Bond \& Cawood, 2021, Nesbit et al., 2020, Senger et al., 2021). Digital outcrop models provide educators with an invaluable tool to promote greater inclusivity that allows students to 'visit' outcrops that are otherwise impossible to access (Senger et al., 2021). One approach to facilitate outcrop 'visits', is to integrate outcrop models into a teaching/training curriculum through virtual field trips (VFTs). Though these are in their infancy compared to traditional field trips, the use of outcrop 
models successfully provides students with an immersive, quantitative experience to learn and visualize concepts (Bond \& Cawood, 2021). VFTs that utilize video game engines have been used to visualize outcrop models (Nesbit et al., 2018), whilst others provide fully interactive virtual landscapes to simulate fieldwork (Houghton et al., 2015, Gonzaga et al., 2018). Immersive VFTs that integrate digital outcrop models and other digital outcrop data to offer multi-scale and multi-participant experiences (Marshall \& Higley, 2021, Métois et al., 2021) can complement traditional fieldwork, or at least a partial replacement for traditional fieldwork for those who simply cannot access outcrops.

As the geoscience community collects and generates more digital outcrops from around the world, digital outcrop databases will provide an invaluable, accessible, and an important long-term archive of key geological outcrops. These databases coupled with integrated VFTs will ultimately help students and scientists' hurdle some of the barriers that traditional fieldwork presents (Fig. 5). As technology advances, so too will fieldwork and fieldtrip experiences.

\section{THE WAY FORWARD}

Outcrops and traditional fieldwork methods are irreplaceable as environments for geological training and scientific advancement. Fundamental geological principles and concepts are most effectively taught 'in the field', yet many outcrops are inaccessible for those with physical disabilities or for marginalized racial, ethnic and gender groups. Outcrops deteriorate, change, or are altered by human activity. However, methods to record and construct digital, photorealistic 2D and 3D representations of outcrops have seen significant advancement over the last decade. This allows for increased preservation potential and conservation of outcrops, and inclusivity through an alternative opportunity to in-field experiences. The user-friendly methods used to construct digital outcrops provide a tool that complements field-based investigation and interpretation, and in doing so, preserves the outcrop and presents an opportunity to enhance the way geoscience is taught.

Notably, the preservation of outcrops that tell the story of the evolution of Earth science provides geoscientists with the 'data' (the outcrops) that underpin the state of our current knowledge. Digital outcrop models give present and future geoscientists access to the landscapes and outcrops that shaped Earth science. Once captured, the digitally preserved outcrops can be archived and stored in databases that could be examined by anyone across the globe. Because re-interpretation and re-examination of outcrops has and will continue to play a crucial role in the progress of the geosciences, digital preservation will help to facilitate access for advancements in science. Ultimately this promotes open access data and sharing, a common goal across all scientific disciplines, and encourages reproducibility - a cornerstone of the scientific method.

The time has never been more appropriate, and the tools never more accessible, to preserve our geological heritage and facilitate greater accessibility, inclusivity, and reproducibility of Earth science.

\section{ACKNOWLEDGMENTS}

We thank Georgina Heldreich for providing useful comments on an early draft of the manuscript. We gratefully acknowledge the detailed and constructive reviews by Kim Senger and two anonymous reviewers, all of which greatly improved the manuscript.

\section{References}

Alexander, J. (1993). A discussion on the use of analogues for reservoir geology. Geological Society, London, Special Publications, 69(1), 175-194. https://doi.org/10.1144/GSL.SP.1993.069.01.08

Anadu, J., Ali, H., \& Jackson, C. (2020). Ten steps to protect BIPOC scholars in the field. Eos, 101. https://doi .org/10.1029/2020E0150525

Bellian, J. A., Kerans, C., \& Jennette, D. C. (2005). Digital outcrop models: Applications of terrestrial scanning lidar technology in stratigraphic modeling. Journal of Sedimentary Research, 75(2), 166-176. https:// doi.org/10.2110/jsr.2005.013

Betlem, P., Birchall, T., Ogata, K., Park, J., Skurtveit, E., \& Senger, K. (2020). Digital drill core models: Structure-from-motion as a tool for the characterisation, orientation, and digital archiving of drill core samples. Remote Sensing, 12(2), 330. https://doi . org/10.3390/rs12020330

Biber, K., Khan, S. D., Seers, T. D., Sarmiento, S., \& Lakshmikantha, M. (2018). Quantitative characterization of a naturally fractured reservoir analog using a hybrid lidar-gigapixel imaging approach. Geosphere, 14(2), 710-730. https://doi.org/10.1130/GES01449.1

Bond, C. E., \& Cawood, A. J. (2021). A role for virtual outcrop models in blended learning - improved 3D thinking and positive perceptions of learning. Geoscience Communication, 4(2), 233-244. https://doi .org/ 10.5194/gc-4-233-2021

Buckley, S. J., Howell, J. A., Naumann, N., Lewis, C., Chmielewska, M., Ringdal, K., Vanbiervliet, J., Tong, B., Mulelid-Tynes, O. S., Foster, D., Maxwell, G., \& Pugsley, J. (2021). V3Geo: A cloud-based repository for virtual 3D models in geoscience. Geoscience Communication Discussions, 1-27. https://doi.org/10.5194/gc-2021-30

Buckley, S. J., Ringdal, K., Naumann, N., Dolva, B., Kurz, T. H., Howell, J. A., \& Dewez, T. J. (2019). LIME: Software for 3-D visualization, interpretation, and communication of virtual geoscience models. Geosphere, 15(1), 222-235. https://doi .org/10.1130/GES02002.1

Burek, C. V., \& Prosser, C. D. (2008). The history of geoconservation: An introduction. Geological Society, London, Special Publications, 300(1), 1-5. https://doi.org/10.1144/SP300.1

Burnham, B. S., \& Hodgetts, D. (2019). Quantifying spatial and architectural relationships from fluvial outcrops. Geosphere, 15(1), 236-253. https://doi.org/10.1130/GES01574.1

Burnham, B. S., Jerrett, R. M., Hodgetts, D., \& Flint, S. S. (2020). Discriminating stacked distributary channel from palaeovalley fill sand bodies in foreland basin settings. Sedimentary Geology, 398, 105592. https://doi.org/10.1016/j. sedgeo.2020.105592

Cawood, A. J., \& Bond, C. E. (2018). 3D mechanical stratigraphy of a deformed multi-layer: linking sedimentary architecture and strain partitioning. Journal of Structural Geology, 106, 54-69. https ://doi .org/ $10.1016 / j . j$ sg.2017.11.011

Cawood, A. J., \& Bond, C. E. (2019). eRock: An open-access repository of virtual outcrops for geoscience education. GSA Today, 29, 36-37. https://doi.org/10.1130/GSATG373GW.1

Cawood, A. J., Bond, C. E., Howell, J. A., Butler, R. W., \& Totake, Y. (2017). LiDAR, UAV or compass-clinometer? Accuracy, coverage and the effects on structural models. Journal of Structural Geology, 98, 67-82. https://doi.org/10.1016/j.jsg.2017.04.004

Chan, M. A., \& Kamola, D. L. (2017). Classic geologic outcrops: Preservation and future accessibility. GSA Today, 27(11), 1-4. https://doi .org/ 10.1130/GSATG343GW. 1

Claerbout, J. F., \& Karrenbach, M. (1992). Electronic documents give reproducible research a new meaning. In SEG Technical Program Expanded Abstracts 1992 (pp. 601-604). Society of Exploration Geophysicists. https://doi.org/10.1190/1.1822162 
Corradetti, A., Seers, T., Billi, A., \& Tavani, S. (2021). Virtual outcrops in a pocket: The smartphone as a fully equipped photogrammetric data acquisition tool. GSA Today, 31, 4-9. https://doi.org/10.1130/ GSATG506A. 1

Demchuk, T., Denison, C., \& O'Keefe, J. (2019). An integrated reevaluation of wilcox/carrizo stratigraphy, bastrop county, texas: Refined chronostratigraphy and revised paleoenvironments. SEPM Special Publication, 111,172-185. https://doi.org/10.2110/sepmsp.111.14

Dowey, N., Barclay, J., Fernando, B., Giles, S., Houghton, J., Jackson, C., Khatwa, A., Lawrence, A., Mills, K., Newton, A., Rogers, S., \& Williams, R. (2021). A UK perspective on tackling the geoscience racial diversity crisis in the Global North. Nature Geoscience, 14(5), 256-259. https://doi.org/10.1038/s41561-021-00737-w

Dutt, K. (2020). Race and racism in the geosciences. Nature Geoscience, 13(1), 2-3. https://doi.org/10.1038/s41561-019-0519-z

Elkins, J. T., \& Elkins, N. M. (2007). Teaching geology in the field: Significant geoscience concept gains in entirely field-based introductory geology courses. Journal of Geoscience Education, 55(2), 126-132. https://doi .org/10.5408/1089-9995-55.2.126

Feig, A. D., Atchinson, C. L., Stokes, A., \& Gilley, B. (2019). Achieving inclusive field-based education: Results and recommendations from an accessible geoscience field trip. Journal of the Scholarship of Teaching and Learning, 19(2), 66-87. https://doi.org/josotl.v19i1.23455

Fernandes, A. M., Abeyta, A., Mahon, R. C., Martindale, R., Bergmann, K. D., Jackson, C., Present, T. M., Reano, D., Swanson, T., Butler, K., Brisson, S., Johnson, C., Mohrig, D., \& Blum, M. D. (2020). “Enriching lives within sedimentary geology": Actionable recommendations for making SEPM a diverse, equitable and inclusive society for all sedimentary geologists. The Sedimentary Record. https://doi.org/ 10.2110/sedred.2020.3

Flaig, P. P., Hasiotis, S. T., \& Fiorillo, A. R. (2018). A paleopolar dinosaur track site in the Cretaceous (Maastrichtian) Prince Creek Formation of Arctic Alaska: Track characteristics and probable trackmakers. Ichnos, 25(2-3), 208-220. https://doi .org/10.1080/10420940.2017.1337011

Flaig, P. P., Hasiotis, S. T., Prather, T. J., \& Burton, D. (2019). Characteristics of a Campanian delta deposit controlled by alternating river floods and tides: The Loyd Sandstone, Rangely Anticline, Colorado, USA. Journal of Sedimentary Research, 89(12), 1181-1206. https://doi.org/ $10.2110 /$ jsr.2019.63

Frébourg, G., Ruppel, S. C., Loucks, R. G., \& Lambert, J. (2016). Depositional controls on sediment body architecture in the Eagle Ford/Boquillas system: Insights from outcrops in west Texas, United States. AAPG Bulletin, 100(4), 657-682. https://doi.org/10.1306/ 12091515101

Geib, C. (2020). The long-term effects of Covid-19 on field science. Eos. https://eos.org/articles/the-long-term-effects-of -covid-19-on-field-science

Gil, Y., David, C. H., Demir, I., Essawy, B. T., Fulweiler, R. W., Goodall, J. L., Karlstrom, L., Lee, H., Mills, H. J., Oh, J.-H., Pierce, S. A., Pope, A., Tzeng, M. W., Villamizar, S. R., \& Yu, X. (2016). Toward the geoscience paper of the future: Best practices for documenting and sharing research from data to software to provenance. Earth and Space Science, 3(10), 388-415. https://doi . org/10.1002/2015EA000136

Giles, S., Jackson, C., \& Stephen, N. (2020). Barriers to fieldwork in undergraduate geoscience degrees. Nature Reviews Earth \& Environment, 1(2), 77-78. https://doi.org/10.1038/s43017-020-0022-5

Gonzaga, L., Veronez, M. R., Kannenberg, G. L., Alves, D. N., Santana, L. G., de Fraga, J. L., Inocencio, L. C., de Souza, L. V., Marson, F., Bordin, F., Tognoli, F. M. W., Senger, K., \& Cazarin, C. L. (2018). A multioutcrop sharing and interpretation system: Exploring 3-D surface and subsurface data. IEEE Geoscience and Remote Sensing Magazine, 6(2), 8-16. https://doi.org/10.1109/MGRS.2018.2825990

Gonzales, L., Keane, C., \& Martinez, C. (2011). Status of the geoscience workforce 2011. https://www. americangeosciences.org/citations/ status-geoscience-workforce-2011

Guzzetti, F., Reichenbach, P., \& Wieczorek, G. (2003). Rockfall hazard and risk assessment in the Yosemite Valley, California, USA. Natural Hazards and Earth System Sciences, 3(6), 491-503. https://doi.org/ 10.5194/nhess-3-491-2003

Hirst, J. (1992). Variations in alluvial architecture across the Oligo-Miocene Huesca fluvial system, Ebro Basin, Spain. https://archives.datapages.com/data/sepm_sp/csp3/
Variations_in_Alluvial_Architecture_Across.htm

Hodgetts, D., Seers, T., Head, W., \& Burnham, B. (2015). High performance visualisation of multiscale geological outcrop data in single software environment. In 77th EAGE Conference and Exhibition 2015 (pp. 1-5). https://doi.org/10.3997/2214-4609.201412862

Houghton, J. J., Lloyd, G. E., Robinson, A., Gordon, C. E., \& Morgan, D. J. (2015). The Virtual Worlds Project: Geological mapping and field skills. Geology Today, 31(6), 227-231. https://doi .org/10.1111/gto.12117

Howell, J. A., \& Burnham, B. S. (2021). The Virtual Geoscience Revolution: From William Smith to virtual outcrop. https://doi.org/10.31223/ X5MS66

Howell, J. A., Chmielewska, M., Lewis, C., Buckley, S., Naumann, N., \& Pugsley, J. (2021). Acquisition of data for building photogrammetric virtual outcrop models for the geosciences using remotely piloted vehicles (RPVs). https://doi.org/10.31223/X54914

Howell, J. A., Eide, C. H., \& Hartley, A. (2018). No evidence for sea level fall in the Cretaceous strata of the Book Cliffs of Eastern Utah https://doi.org/10.31223/osf.io/2ju3d

Howell, J. A., Martinius, A. W., \& Good, T. R. (2014). The application of outcrop analogues in geological modelling: A review, present status and future outlook. Geological Society, London, Special Publications, 387(1), 1-25. https://doi.org/10.1144/SP387.12

Hutton, J. (1795). Theory of the earth, with proofs and illustrations (Vol. 1). Edinburgh.

Kastens, K. A., Manduca, C. A., Cervato, C., Frodeman, R., Goodwin, C., Liben, L. S., Mogk, D. W., Spangler, T. C., Stillings, N. A., \& Titus, S. (2009). How geoscientists think and learn. Eos, Transactions American Geophysical Union, 90(31), 265-266. https://doi.org/10.1029/ 2009E0310001

Kuckero, L., Betlem, P., Smyrak-Sikora, A., Birchall, T., \& Senger, K. (2020). Festningen-A digital field guide (DigFest). iEarth Educational Research Publication Series, 1.

Marín-Spiotta, E., Barnes, R. T., Berhe, A. A., Hastings, M. G., Mattheis, A., Schneider, B., \& Williams, B. M. (2020). Hostile climates are barriers to diversifying the geosciences. Advances in Geosciences, 53, 117-127. https://doi.org/10.5194/adgeo-53-117-2020

Marshall, M. S., \& Higley, M. C. (2021). Multi-scale virtual field experience: Sedimentology and stratigraphy of Grand Ledge, Michigan, USA. Geoscience Communication, 4(4), 461-474. https://doi.org/10.5194/ gc-4-461-2021

Martin, B., Owen, A., Nichols, G. J., Hartley, A. J., \& Williams, R. D. (2021). Quantifying downstream, vertical and lateral variation in fluvial deposits: Implications from the Huesca Distributive Fluvial System. Frontiers in Earth Science, 8, 733. https://doi .org/10.3389/feart.2020 .564017

McCaffrey, K., Jones, R., Holdsworth, R., Wilson, R., Clegg, P., Imber, J., Holliman, N., \& Trinks, I. (2005). Unlocking the spatial dimension: Digital technologies and the future of geoscience fieldwork. Journal of the Geological Society, 162(6), 927-938. https://doi.org/10.1144/ 0016-764905-017

McNutt, M. (2014). Journals unite for reproducibility. Science, 346(6210), 679-679. https://doi.org/10.1126/science. aaa1724

Métois, M., Martelat, J.-E., Billant, J., Andreani, M., Escartín, J., Leclerc, F., \& ICAP. (2021). Deep oceanic submarine fieldwork with undergraduate students, an exceptional immersive experience (Minerve software). Solid Earth Discussions, 1-17. https://doi.org/10.5194/se-2021-89

Mitten, A., Howell, L., Clarke, S., \& Pringle, J. (2020). Controls on the deposition and preservation of architectural elements within a fluvial multi-storey sandbody. Sedimentary Geology, 401, 105629. https:// doi.org/10.1016/j.sedgeo.2020.105629

Nature. (2016). Reality check on reproducibility. Nature, 533(May 25), 437. https://doi.org/10.1038/533437a

Nesbit, P. R., Boulding, A. D., Hugenholtz, C. H., Durkin, P. R., \& Hubbard, S. M. (2020). Visualization and sharing of 3D digital outcrop models to promote open science. GSA Today, 30(6), 4-10. https://doi.org/10.1130/GSATG425A.1

Nesbit, P. R., Durkin, P. R., Hugenholtz, C. H., Hubbard, S. M., \& Kucharczyk, M. (2018). 3-D stratigraphic mapping using a digital outcrop model derived from UAV images and structure-from-motion photogrammetry. Geosphere, 14(6), 2469-2486. https://doi .org/10.1130/ GES01688.1

Nutman, A. P., Bennett, V. C., Friend, C. R., \& Van Kranendonk, M. (2019). 
The Eoarchean legacy of Isua (Greenland) worth preserving for future generations. Earth-Science Reviews, 198, 102923. https://doi.org/ 10.1016/j. earscirev.2019.102923

Olcott, A., \& Downen, M. (2020). The challenges of fieldwork for LGBTQ+ geoscientists. Eos, 101, 22-24. https://doi.org/10.1029/ 2020E0148200

Pattison, S. A. (2019). Using classic outcrops to revise sequence stratigraphic models: Reevaluating the Campanian Desert Member (Blackhawk Formation) to lower Castlegate Sandstone interval, Book Cliffs, Utah and Colorado, USA. Geology, 47(1), 11-14. https://doi.org/ 10.1130/G45592.1

Piatek, J. L., Kairies Beatty, C. L., Beatty, W. L., Wizevich, M. C., \& Steullet, A. (2012). Developing virtual field experiences for undergraduates with high-resolution panoramas (GigaPans) at multiple scales. In Google Earth and Virtual Visualizations in Geoscience Education and Research. Geological Society of America. https://doi.org/10.1130/2012.2492(21)

Pitts, A. D., Casciano, C. I., Patacci, M., Longhitano, S. G., Di Celma, C., \& McCaffrey, W. D. (2017). Integrating traditional field methods with emerging digital techniques for enhanced outcrop analysis of deep water channel-fill deposits. Marine and Petroleum Geology, 87, 2-13. https://doi.org/10.1016/j . marpetgeo.2017.05.001

Rittersbacher, A., Howell, J. A., \& Buckley, S. J. (2014). Analysis of fluvial architecture in the Blackhawk Formation, Wasatch Plateau, Utah, USA, using large 3D photorealistic models. Journal of Sedimentary Research, 84(2), 72-87. https://doi.org/10.2110/jsr. 2014.12

Romans, B. W., \& Graham, S. A. (2013). A deep-time perspective of landocean linkages in the sedimentary record. Annual Review of Marine Science, 5, 69-94. https://doi.org/10.1146/annurev-marine-121211 $-172426$

Rossa, P., Horota, R. K., Junior, A. M., Aires, A. S., De Souza, E. M., Kannenberg, G. L., De Fraga, J. L., Santana, L., Alves, D. N., Boesing, J., Gonzaga, L., Veronez, M. R., \& Cazarin, C. L. (2019). Mosis: Immersive virtual field environments for earth sciences. In 2019 IEEE Conference on Virtual Reality and 3D User Interfaces (VR) (pp. 1140-1141). https:// doi.org/10.1109/VR.2019.8797909

Schwab, M., Karrenbach, M., \& Claerbout, J. (1995). Reproducible electronic documents. https://doi.org/10.1190/1.1822162

Senger, K., Betlem, P., Birchall, T., Buckley, S. J., Coakley, B., Eide, C. H., Flaig, P. P., Forien, M., Galland, O., Gonzaga Jr, L., Jensen, M., Kurz, T., Lecomte, I., Mair, K., Malm, R. H., Mulrooney, M., Naumann, N., Nordmo, I., Nolde, N., Ogata, K., Rabbel, O., Schaaf, N. W., \& SmyrakSikora, A. (2021). Using digital outcrops to make the high Arctic more accessible through the Svalbox database. Journal of Geoscience Education, 69(2), 123-137. https://doi.org/10.1080/10899995.2020.1813865

Sima, R. (2020). Accessibility and fieldwork in the time of coronavirus. Eos, 101. https://doi .org/10.1029/2020E0147056

Stokes, A., Feig, A. D., Atchison, C. L., \& Gilley, B. (2019). Making geoscience fieldwork inclusive and accessible for students with disabilities. Geosphere, 15(6), 1809-1825. https://doi.org/10.1130/GES02006.1

Tavani, S., Corradetti, A., Vinci, F., Parente, S., M.and Mazzoli, Morsalnejad, D., \& Iannace, A. (2020). Virtual geological mapping in the Lurestan region of the Zagros with Google Earth. Geological Field Trips and Maps, 12(2.1), 1-11. https://doi.org/10.3301/GFT.2020.03

Tretinjak, C. A., \& Riggs, E. M. (2008). Enhancement of geology content knowledge through field-based instruction for pre-service elementary teachers. Journal of Geoscience Education, 56(5), 422-433. https:// doi.org/10.5408/jge_nov2008_riggs_422

Van Der Kolk, D. A., Flaig, P. P., \& Hasiotis, S. T. (2015). Paleoenvironmental reconstruction of a late cretaceous, muddy, river-dominated polar deltaic system: Schrader Bluff-Prince Creek Formation transition, Shivugak bluffs, north slope of Alaska, USA. Journal of Sedimentary Research, 85(8), 903-936. https://doi.org/10.2110/jsr.2015.58

Van Wagoner, J. C., Mitchum, R., Campion, K., \& Rahmanian, V. (1990). Siliciclastic sequence stratigraphy in well logs, cores, and outcrops: Concepts for high-resolution correlation of time and facies. AAPG Special Volumes: AAPG Methods in Exploration Series, No. 7. https://archives.datapages.com/data/specpubs/seismic2/data/ a174/a174/0001/0000/iii.htm

Weissmann, G., Hartley, A., Nichols, G., Scuderi, L., Olson, M., Buehler, H., \& Banteah, R. (2010). Fluvial form in modern continental sedimentary basins: Distributive fluvial systems. Geology, 38(1), 39-42. https:// doi.org/10.1130/G30242.1
Whitmeyer, S. J., Mogk, D. W., \& Pyle, E. J. (2009). An introduction to historical perspectives on and modern approaches to field geology education. Geological Society of America Special Papers, 461, vii-ix. https://doi.org/10.1130/2009.2461(00)

Wignall, R. M., Gordon, J. E., Brazier, V., MacFadyen, C. C., \& Everett, N. S. (2018). A qualitative risk assessment for the impacts of climate change on nationally and internationally important geoheritage sites in Scotland. Proceedings of the Geologists' Association, 129(2), 120-134. https://doi.org/10.1016/j.pgeola.2017.11.003

Wilkinson, B. H. (2005). Humans as geologic agents: A deep-time perspective. Geology, 33(3), 161-164. https://doi.org/10.1130/G21108.1

Wilkinson, M. D., Dumontier, M., Aalbersberg, I. J., Appleton, G., Axton, M., Baak, A., Blomberg, N., Boiten, J., da Silva Santos, L., Bourne, P., Bouwman, J., Brookes, A. J., Clark, T., Crosas, M., Dillo, I., Dumon, O., Edmunds, S., Evelo, C. T., Finkers, R., Gonzalez-Beltran, A., Gray, A. J. G., Groth, P., Goble, C., Grethe, J. S., Heringa, J., Hoen, P. A. C. Hooft, R., Kuhn, T., Kok, R., Kok, J., Lusher, S. J., Martone, M. E., Mons, A., Packer, A. L., Persson, B., Rocca-Serra, P., Roos, M., van Schaik, R., Sansone, S.-A., Schultes, E., Sengstag, T., Slater, T., Strawn, G., Swertz, M. A., Thompson, M., van der Lei, J., van Mulligen, E., Velterop, J., Waagmeester, A., Wittenburg, P., Wolstencroft, K., Zhao, J., \& Mons, B. (2016). The FAIR Guiding Principles for scientific data management and stewardship. Sci Data, 3(160018). https://doi.org/10.1038/sdata.2016.18

Xu, X., Aiken, C. L., Bhattacharya, J. P., Corbeanu, R. M., Nielsen, K. C., McMechan, G. A., \& Abdelsalam, M. G. (2000). Creating virtual 3-D outcrop. The Leading Edge, 19(2), 197-202. https://doi .org/10.1190/ 1.1438576 